\title{
THE ALGERIAN ECONOMY GOVERNED BY BLACK CORRUPTION: AN EMPIRICAL STUDY FROM 2002 TO 2015
}

\author{
Midoun Sissani \\ Faculty of Economic, Management and Commercial Sciences, \\ University Ibn- Khaldoun, Tiaret (14000), Algeria \\ sissanim@gmail.com
}

\begin{abstract}
The main objective of this paper is to highlight the concept of corruption and analyses our cumulative knowledge about corruption's effects on the economic growth in Algeria during the period 2002-2015. This article emphasizes the major source of corruption and how the quality of institutions and government policies could mitigate the risk of corruption or increase it. The findings also show the great role of free media in most developing countries which created a new tendency to talk about the effects of corruption especially in recent years. Using a multiple regression model, we find that a $1 \%$ decrease in the corruption index CPI level increases the GDP growth rate by approximately 2,005\%. The analysis also revealed that there is a negative relationship between the country rank and the economic growth. Finally, the results suggest that more economic freedom, social and political stability lead to less corruption.
\end{abstract}

\section{Keywords}

corruption; political economy; government policy

\section{JEL Classification}

D73; G28; P48

\section{Introduction}

No doubt that Algeria and a lot of countries around the world are still suffering from corruption which is rampant in the poorest countries and represents a great danger on the cultural and moral values. Besides, it slows down the economic growth and has a big influence on the continuity of all reforms suggested or planned by some developing countries. Algeria is among the countries sunken in corruption, especially with the slump of oil costs which recently plunged back below 40 dollars in 2016. The Algerian economy trends towards a harsh financial crisis which may not only consume all the foreign currency reserves during the three coming years at most and may push the weak government to go back to borrowing as well.

Unfortunately, corruption is always there where there is an absence of public ethics and the absence of governance. Since the oldest history, corruption has existed under different names such as frauds, bribes, robberies, the squandering of public money besides the influence peddling which is based on illegal practice or political influence to get advantages and preferential treatment in exchange for money. This phenomenon has led Algeria's government to the dustbin of history and most parliaments are conspirators and corruption has extended over a lot of public sectors. Policy makers in Algeria are also sinking increasingly in corruption. In contrast, this situation may have a negative effect on the distribution of the Algerian incomes. Without transparency and accountability, corruption is growing up and viewed as a modern ethic in the psychological and mental characteristics of any Algerian. Many studies have shown the importance of studying corruption and have tried to find the most important factors which push people to enter in corrupt activities. In our study, we try to focus on 
corruption which runs rampant in Algeria. This cancer is slowly killing social ethics and the economic growth.

\section{Literature review}

Definitely, Globalization has contributed to the wide spreading of corruption especially because it was founded on the removal of borders and the protectionist laws. Both cross-border business and multinational companies have increased corruption opportunities in the world under a suspicious policy umbrella. Eventually, a lot of states in the world and among them, Algeria, have encouraged implicitly corrupt politicians and the owners of wealth in smashing the society ethics and this phenomenon has led to public disgust. The literature has pointed out the negative impact of corruption on economic growth, stability, social morality, and especially concerning the legitimacy of the state and the way political power is exercised.

a. (Jain, Arvind K, 2001) According to this researcher, corruption represents a major threat to economic development and using a survey he tried to identify the different factors that deter or facilitate and favour corruption and he made some suggestions to reduce corruption.

b. (Warren, Mark E, 2004). The author provided a moderate concept of corruption in his paper and he demonstrated that corruption is the inappropriate use of power over collective decisions and here democracy depends on the voters and political opposition in the case that they can replace corrupt leaders or not .So, the degree of awareness among voters, associations and political parties and they represent the seed which leads to the failure or the success of democracy itself. On other hand, corruption creates inefficiencies in deliveries of public services and the shifting of these services to other sectors to benefit from bribes.

c. (Ghulam Shabbir and Mumtaz Anwar, 2007). In their article entitled the "Determinants of Corruption in Developing Countries", they noticed that corruption is one of the most dangerous phenomena that destroy the institutional foundation and the government social policy and it may lead to the public and private misallocation of resources. They also mentioned that corruption represents a real challenge for policy makers and they divided the corruption determinants into two parts: economic and non-economic ones and they found out that the most important determinants that matter more are the economic determinants such as economic freedom, education and Globalization.

d. (Alt, James E., and David Dreyer Lassen, 2003). They focused on the relationship between corruption and institutions in the United States. Using a regression model in their article "The political economy of institutions and corruption in American states" they tried to make the point theoretically and empirically and they concluded that political institutions have a great role in explaining the prevalence of corruption.

e. (Drury, Krieckhaus and Lusztig, 2006). He analyzed the impact of corruption in democracies and non-democracies in the period between 1982 and 1997. He concluded that corruption can freeze the economic growth in authoritarian regimes.

f. (Axel Dreher Friedrich Schneider, 2010). This article is among the best articles focuses and emphasizes on the need of the state's intervention in the economy to combat the shade economy. It also analyzes the relationship between the shade economy and corruption. In this article, the researchers find a strong significant impact of the shadow economy on corruption especially in low income countries. However, there is no robust relation in high income countries. 


\section{Corruption definition}

There is no precise or universally accepted definition of corruption but there is a sort of consensus that corruption has a detrimental effect on the social welfare and the economic development. Various definitions are found according to different approaches and schools. World Bank defines corruption as: "the abuse of public office for private profits when an official accepts solicits or extorts bribes" (1997: 8)." This means that corruption is the misuse of entrusted power for private gain. In the same context, The United Nations Development Programs (UNDP) defined corruption as accepting money "... for doing something that one is under the duty to do or that one is under the duty not to do " (2000: 167). On the other hand, corruption is a sort of deviation from the formal duties of the public role and it refers to the acts in which power and influence of the public office is used for personal gain.

\subsection{Corruption typology and measurement}

\subsubsection{Corruption typology}

Corruption can be classified into numerous main forms: Grand, Petty and political corruption. Researchers have provided many classifications but these classifications remain subjective and they depend on their impact on the economic or social field (Okew, 2015).

1) Grand corruption: It is a crime at a high level of government that distort policies or the central functioning of the state. This kind of corruption increases the poverty of thousands or millions of people in any country where corruptors, especially the country leaders, benefit at the expense of the public good.

2) Petty corruption: It refers to the engagement in some activities that are far from the social norms and the abuse of entrusted power by low- and mid-level public officials in their interactions with ordinary citizens, who often try to access basic goods or services.

3) Political corruption: is exploitation of policies, institutions and rules of procedure in the allocation of resources and financing by political decision makers, who abuse to increase their position and sustain their power, status and wealth.

4) Systemic corruption: Very widespread in Algeria and encouraged by the system itself and this sort of corruption dominates the major processes and institutions of the state. Corruption becomes an essential and integrated aspect of the society.

5) Administrative corruption: includes bribery and favoritism and the civil servants try to live beyond their legal income. This kind of corruption emerges when the society loses its behavior and cultural values and the civil servants became a tool that businesses can buy to pay lower taxes or to gain access to low-level procurement contracts.

However, there are some searchers who divided corruption into bribery, embezzlement, fraud and extortion.

\section{Table 1 Forms of Corruption}

\begin{tabular}{|l|l|}
\hline Bribery & $\begin{array}{l}\text { Bribery is the act of promising, giving, receiving, or agreeing to receive } \\
\text { money in return for preferential treatment or government services. }\end{array}$ \\
\hline Embezzlement & $\begin{array}{l}\text { Embezzlement is to steal money despite being entrusted to take care of it. } \\
\text { It occurs when someone who was entrusted to manage or monitor } \\
\text { someone else's money or property steals all or part of that money or } \\
\text { property for the taker's personal gain. }\end{array}$ \\
\hline
\end{tabular}




\begin{tabular}{|l|l|}
\hline Fraud & $\begin{array}{l}\text { Economic crime and deception practice that involves some kind of } \\
\text { trickery, swindle and deceit in order to gain unlawful or unfair advantage. } \\
\text { It is the process of cheating to obtain financial gains. }\end{array}$ \\
\hline Extortion & $\begin{array}{l}\text { Extortion occurs when one person forces another person to do something } \\
\text { against his will, generally to give up money or other property, by threat of } \\
\text { violence. }\end{array}$ \\
\hline $\begin{array}{l}\text { Nepotism and } \\
\text { Cronyism }\end{array}$ & $\begin{array}{l}\text { Nepotism is favoritism in the public administration, appointments and } \\
\text { secure contacts or securing contracts to relatives, family ties and close } \\
\text { relationship regardless of whether it is deserved or not. However, cronyism } \\
\text { is an unfair practice through offering jobs and other advantages to friends } \\
\text { or trusted colleagues by powerful politicians. }\end{array}$ \\
\hline
\end{tabular}

Source: Prepared by the author from different sources

\subsubsection{Measurement of corruption}

Corruption is a very sensitive topic and it is very hard to measure it. Thus, we have to look for a range of control mechanisms in order to reduce corruption. These measures are as follows:

a. Corruption perception index: The Corruption Perceptions Index (CPI) is among the best tools in measuring corruption. It was launched in 1995. In 2011 CPI measures the perceived levels of public sector corruption in 183 countries and territories around the world and actually the (CPI)ranks 200 countries on a scale of zero to 10 , with zero indicating high levels of corruption and 10 indicating low levels. This definition encompasses corrupt practices in both the public and private sectors (Seligson, 2002).

b. Global Corruption Barometer: The Global Corruption Barometer is a public opinion survey. The Barometer deals with citizens, who faced, were exposed or suffered from petty bribery and their experience with institutions and public services most affected by bribery. It also deals with individual and peoples experiences with corruption in their countries. This index was created in 2003 and it measures corruption in more than 100 countries in the world. It became one of the largest cross-country surveys which collected the general public's views on corruption, especially people's experiences with corruption. In 2010 and 2011 the Barometer succeeded to interview more than 100,000 people.

c. Political Risk index: The Country risk guide comprises 22 variables in three subcategories of risk: the economic risk, financial risk and the political risk. The last one assesses corruption and other components such as the government stability and ethnic tensions etc.

The factors that facilitate corruption are:

- Politic instability;

- Weak governance;

- Educational weakness and the non-respect of ethics;

- The justice system;

- Weak institutions;

- Absence of accountability.

\section{Algeria's efforts to combat corruption}

Understanding corruption in its proper context is not easy because its determinants and its intensity differ from a state to another and from a geographical place to another. Concerned about the threat posed by corruption, Algeria introduced some laws and legislation to reduce the impact of corruption and prevent the theft of the public money. Algeria took part in and signed the United Nation convention against corruption in 2004 issued the 2006 law to fight against it through specialized services. Unfortunately, 
corruption is widespread in most government institutions and the media have published recent reports about politicians and governmental leaders' scandals after using their political power abusively to gather private enrichments. Nevertheless, the long civil war between 1992 and 2000, military influence, corruption, and cronyism have remained prevalent up to this day (Sissani and Belkacem, 2014).

Although the legal framework criminalizes a large range of corruption offenses, the Algerian economy is still suffering from this danger called corruption and if we have a look at the chart (1) we can see obviously that Algeria was in the $84^{\text {th }}$ rank according to the corrupt national transparency out of 175 countries in 2006 and scored 3.1 in the Corruption Perceptions Index. However, after making some important economic and legislative reforms, the corruption did not decrease but it intensified and Algeria's rank became 105 out of 175 countries in 2010. In 2011, its rank worsened and occupied the $112^{\text {th }}$ rank out of 175 countries in the world. Once again, in 2014 Algeria received a score of 3.6 out of 10 , which places it on the $100^{\text {th }}$ place. Fortunately, it has improved its ranking in 2015 and occupied the $88^{\text {th }}$ place by obtaining a 3.6 out of 10 in the international corruption index.

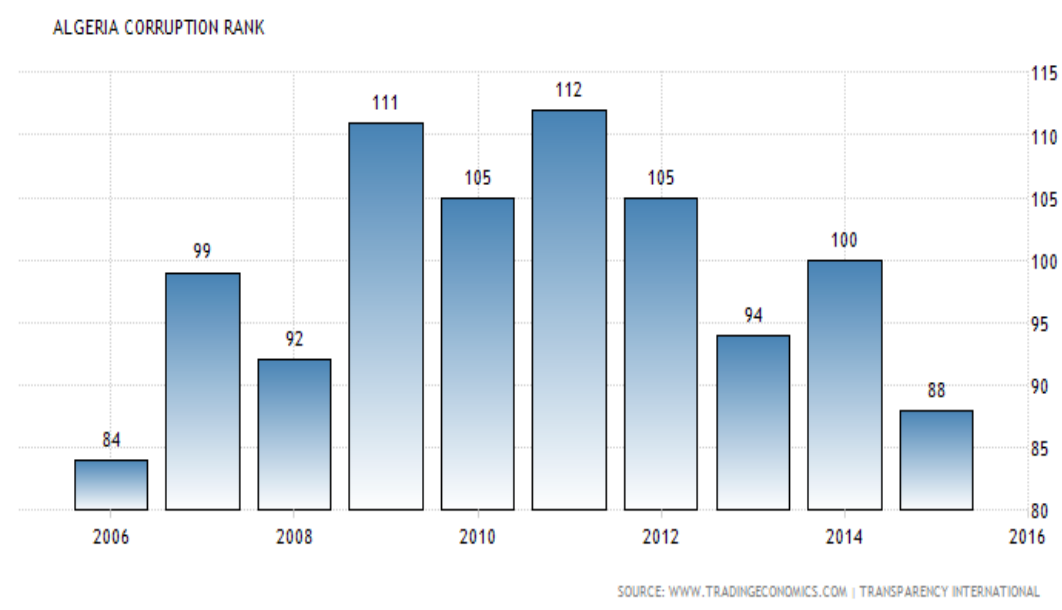

Chart 1 Algeria Corruption Index from 2006 to 2015

Source: Trading economic, From: tradingeconomics.com/algeria/corruption-rank

No doubt that international companies which are operating or intend to invest in Algeria face the problem of bribes and nepotism and they often find a great political and economic risk (Sissani and Belkacem, 2014) while dealing with the public services. The corruption file emerged with the embezzlements and bribes linked to the state company called "Sonatrach" in 2015 and which revealed the implication of officials and ministers in the corruption scandal and some economists estimate that corruption has harvested more than $\$ 30$ billion dollars during the past ten years.

\section{Data and methodology}

The dependent variable in this study is the GDP per capita. The independent variables are: Corruption perception index (CPI), The Inflation rate, International corruption rank, Unemployment (percent) and The Poverty rate. The period from 2002 to 2015 is 
chosen to study the relationship and the impact of corruption and other economic variables on the Growth rate in Algeria. Both the corruption index and rank are obtained from Transparency international web site. We use 14 observations in our regression and this may pose some problems with the observation size but we can avoid them with other tests. In our study, we will use the ordinary least squares method (OLS).

The study model is formulated as follows. The dependent variable is 'GDP Per Capita' and the data were extracted from the African Statistical year book issues (2013, 2014, 2016). However, the independent variables are obtained from (CPI) and the Algerian governmental agencies sites (Cnes and Ones) and they are explained below:

Where:

$$
\text { GDP Rate }=\beta 0+\beta 1 \cdot \mathrm{X} 1+\beta 2 \cdot \mathrm{X} 2+\beta 3 \cdot \mathrm{X} 3+\beta 4 \mathrm{X} 4+\beta 5 \cdot \mathrm{X} 5+\varepsilon_{i}
$$

$$
\begin{array}{ll}
\checkmark & \beta 0=\text { the intercept. } \\
\checkmark & \beta 1 \text { to } \beta 5=\text { the partial slope coefficients. } \\
\checkmark & \text { Rank (X1): International corruption Rank. } \\
\checkmark & \text { Cpi (X2): International corruption index. } \\
\checkmark & \text { Inf (X3): Inflation rate (Percent). } \\
\checkmark & \text { Unemployment (X4) : Unemployment (percent). } \\
\checkmark & \text { Poverty Rate (X5): Poverty rate. }
\end{array}
$$

We focus our investigation model on corruption (Cpi) and the International Corruption Rank and their impact on GDP in Algeria. $\varepsilon_{\mathrm{i}}$ is an error term that captures measurement errors and unobserved determinants of output.

Table 2 Data inserted in Multiple linear regression (MLR) modal

\begin{tabular}{|l|l|l|l|l|l|l|}
\hline Years & \multicolumn{1}{|c|}{$\begin{array}{c}\text { X1 } \\
\text { Rank }\end{array}$} & $\begin{array}{c}\text { X2 } \\
\text { CPI }\end{array}$ & $\begin{array}{c}\text { X3 } \\
\text { INF }\end{array}$ & $\begin{array}{c}\text { X4 } \\
\text { Unemp }\end{array}$ & $\begin{array}{c}\text { X5 } \\
\text { Poverty } \\
\text { Rate }\end{array}$ & $\begin{array}{c}\text { Y } \\
\text { GDP } \\
\text { Growth } \\
\text { rate }\end{array}$ \\
\hline $\mathbf{2 0 1 5}$ & 88 & 3.6 & 4.8 & 11,20 & 11,2 & 3,9 \\
\hline $\mathbf{2 0 1 4}$ & 100 & 3.6 & 2.9 & 10,60 & 7 & 3,3 \\
\hline $\mathbf{2 0 1 3}$ & 94 & 3.6 & 3.3 & 9,8 & 5,03 & 3,8 \\
\hline $\mathbf{2 0 1 2}$ & 105 & 3.4 & 8.9 & 11 & 5,20 & 2,6 \\
\hline $\mathbf{2 0 1 1}$ & 112 & 2.9 & 4.5 & 9,80 & 5 & 4,0 \\
\hline $\mathbf{2 0 1 0}$ & 105 & 2.9 & 3.9 & 10,00 & 6,2 & 2,4 \\
\hline $\mathbf{2 0 0 9}$ & 111 & 2.8 & 5.7 & 10,20 & 5,1 & 3,5 \\
\hline $\mathbf{2 0 0 8}$ & 92 & 3.2 & 4.9 & 11,30 & 5,2 & 3,2 \\
\hline $\mathbf{2 0 0 7}$ & 99 & 3.0 & 3.7 & 13,88 & 5,7 & 4,6 \\
\hline $\mathbf{2 0 0 6}$ & 84 & 3.1 & 2.3 & 12,30 & 23 & 5,4 \\
\hline $\mathbf{2 0 0 5}$ & 97 & 2.8 & 1.4 & 15,75 & 5,7 & 5,1 \\
\hline $\mathbf{2 0 0 4}$ & 97 & 2.7 & 4.0 & 17,70 & 6,4 & 5,2 \\
\hline $\mathbf{2 0 0 3}$ & 88 & 2.6 & 4.3 & 23,71 & 8 & 6,8 \\
\hline $\mathbf{2 0 0 2}$ & 96 & 2.7 & 1.4 & 25,66 & 8,5 & 4,1 \\
\hline
\end{tabular}

Source: Transparency international reports (2002 to 2015)

African statistical year book, AfDB, 2016, p. 56, from: http://www.afdb.org/

* We removed (X4) which represents the unemployment variable and (X5) which represents poverty rate because when we run the regression with these two independent variables, an insignificant model results. See table (3). 
Table 3 The coefficients of the estimated model

\begin{tabular}{|c|c|c|c|c|c|c|}
\hline \multicolumn{7}{|c|}{ Coefficients $^{\mathrm{a}}$} \\
\hline \multirow{2}{*}{\multicolumn{2}{|c|}{ Model }} & \multicolumn{2}{|c|}{$\begin{array}{c}\text { Unstandardized } \\
\text { Coefficients }\end{array}$} & $\begin{array}{l}\text { Standardized } \\
\text { Coefficients }\end{array}$ & \multirow[t]{2}{*}{$\mathrm{t}$} & \multirow[t]{2}{*}{ Sig. } \\
\hline & & B & Std. Error & Beta & & \\
\hline \multirow[t]{6}{*}{1} & (Constant) & 6,557 & 5,653 & & 1,160 & 0,280 \\
\hline & Rank & $-0,039$ & ,048 &,- 274 &,- 810 & 0,442 \\
\hline & Cpi & $-0,014$ & 023 &,- 162 &,- 603 & 0,563 \\
\hline & Inf & $-0,024$ &, 179 &,- 038 &,- 136 & 0,895 \\
\hline & Unemp & 0,102 & 067 &, 454 & 1,518 & 0,168 \\
\hline & Pov Rate & 0,028 & 081 &, 113 & ,347 & 0,737 \\
\hline
\end{tabular}

\section{Results}

In this empirical analysis, we have tried to find the impact of some selected macroeconomic variables such as inflation rate, the corruption index, Rank, and their impact on the GDP Rate based on a 5.0 percent.

In the first table (4) entitled the model summary, the value of the correlation coefficient is $\mathrm{R}$ value $=0.79$; however, the $\mathrm{R}$ square value $\mathrm{R} 2=0.62$ means that this model expresses about $62 \%$ of the data and $38 \%$ can be related to other independent variables.

Table 4 The model summary

\begin{tabular}{|l|c|c|c|c|c|c|}
\hline \multicolumn{7}{|c|}{ Model Summary $^{\mathbf{b}}$} \\
\hline
\end{tabular}

Source: author compilation

The next table is the ANOVA table, which shows us how well the regression equation fits our inserted data. According to the Analysis of Variance table which is summarized in the output of Anova table (5), the significance value is (0.016), which is below (0.05) and less than the critical value of alpha. So, the null hypothesis is rejected and the alternative hypothesis which assumes that there is a significant difference between the groups is taken. Besides, The Sig Value shows us that the whole model has a great statistical significance.

Table 5 ANOVA and the significance of the model

\begin{tabular}{|c|c|c|c|c|c|c|}
\hline \multicolumn{7}{|c|}{ ANOVA $^{b}$} \\
\hline \multicolumn{2}{|c|}{ Model } & $\begin{array}{l}\text { Sum of } \\
\text { Squares }\end{array}$ & $\mathrm{df}$ & Mean Square & $\mathrm{F}$ & Sig. \\
\hline \multirow[t]{3}{*}{1} & Regression & 11,849 & 3 & 3,950 & 5,614 & $0,016^{\mathrm{a}}$ \\
\hline & Residual & 7,035 & 10 & ,703 & & \\
\hline & Total & 18,884 & 13 & & & \\
\hline \multicolumn{7}{|c|}{ a. Predictors: (Constant), Infl, Cpi, Rank } \\
\hline \multicolumn{7}{|c|}{ b. Dependent Variable: GDP Rate } \\
\hline
\end{tabular}

Source: author's compilation 
Table (6) presents the coefficients and it determines how much the independent variables (the inflation, corruption and the corruption rank) contribute statistically and significantly. From the output, it has been removed the inflation rate where the sig value was $=0.839$, which means that this variable is not statistically significant. However, all other variables are statistically significant. The intercept (Constant) sig value is 0.001 . Finally, the Rank sig value is 0.021 and the Cpi sig value is 0.017 and both of them are below the alpha value.

Table 6 The coefficients of the estimated model

\begin{tabular}{|c|c|c|c|c|c|c|}
\hline \multicolumn{7}{|c|}{ Coefficients $^{\mathbf{a}}$} \\
\hline \multirow{2}{*}{\multicolumn{2}{|c|}{ Model }} & \multicolumn{2}{|c|}{ Unstandardized Coefficients } & \multirow{2}{*}{$\begin{array}{c}\begin{array}{c}\text { Standardized } \\
\text { Coefficients }\end{array} \\
\text { Beta } \\
\end{array}$} & \multirow[b]{2}{*}{$\mathrm{t}$} & \multirow[b]{2}{*}{ Sig. } \\
\hline & & $\mathrm{B}$ & Std. Error & & & \\
\hline \multirow[t]{4}{*}{1} & (Constant) & 18,65 & 3,944 & & 4,730 & 0,001 \\
\hline & Rank & $-0,085$ & ,031 &,- 591 & $-2,722$ & 0,021 \\
\hline & Cpi & $-2,005$ & 697 &,- 597 & $-2,875$ & $\begin{array}{ll} & 0,0 \\
17 & \\
\end{array}$ \\
\hline & Infl &,- 029 &, 140 &,- 046 &,- 208 & 0,839 \\
\hline
\end{tabular}

\section{Conclusion and discussion}

In this study, we try to investigate various economic and non-economic independent variables as determinants which have a great influence on the dependent variable (DGP rate). Our main purpose was to see if corruption has a significant linkage with the DGP growth rate. It was confirmed that the impact of corruption is quite a serious problem, which has a great effect on the economic performance especially in developing countries such as Algeria.

What distinguishes this study is that there is a negative causal relationship between corruption and the GDP growth rate. When corruption CPI (which is a sort of scale from 10 highly clean to 0 highly corrupt) decreases with one degree, the GDP rate increases with 2,005 percent. This paper has attempted to assess the impact of corruption in Algeria which is a wealthy country due to its resources but its people live in poverty. From the argument given above, we can also observe that when the country rank increases with one position, the GDP Rate increases with 0.085 .

To reduce the level of corruption, the government has to create an anti-corruption committee or cell in all the public sectors and to train employees to face corruptors and any corruption situation. It is also important to train the workers and officers to write reports to the responsible ones if they detect any suspicious activities. Previous studies have demonstrated the impact of corruption and its linkage with the income, the government Budgets or its impact on poverty (Mauro, 1998).

Certainly, the reasons for the wide spreading of the phenomenon of corruption is linked first to the absence of the strong legislative anti-corruption framework besides the low freedom given to the judiciary system and the lack of liberty in the media which is still under the political umbrella. Combating corruption is a real challenge in Algeria. For example, in recent surveys made by the Global Corruption Barometer, they found that 50 million adults in Algeria and North African countries pay bribes to access basic services. 


\section{References}

Alt, J. E., \& Lassen, D. D. (2003), The political economy of institutions and corruption in American states, Journal of Theoretical Politics, 15(3), pp.346-360.

Dreher, A., \& Schneider, F. (2010), Corruption and the shadow economy: an empirical analysis, Public Choice, 144(1-2), pp.215-238.

Drury, A. C., Krieckhaus, J., \& Lusztig, M. (2006), Corruption, democracy, and economic growth, International Political Science Review, 27(2), pp. 121-136.

Jain, A. K. (2001), Corruption: A review, Journal of economic surveys, 15(1), p.73.

Mauro, P. (1998), Corruption and the composition of government expenditure, Journal of Public economics, 69(2), pp. 263-279.

Okewu, E., \& Okewu, J. (2015), E-government, e-Governance and e-Administration: A Typology of Corruption Management Using ICTs, In Proceedings of the 15th European Conference on eGovernment . Academic Conferences Limited.

Seligson, M. A. (2002), The impact of corruption on regime legitimacy: A comparative study of four Latin American countries, Journal of politics, 64(2), p 421.

Shabbir, G., \& Anwar, M. (2007), Determinants of corruption in developing countries, The Pakistan Development Review, pp.751-764.

Sissani, M., \& Belkacem, Z. (2014), The Effect of Political Risk on Foreign Direct Investment: The Case of Algeria, Hyperion Economic Journal, 2(3), p.30.

Sissani, M., \& Belkacem, Z. (2014), The Impact Of Country Risk Components On Algeria Attractiveness For Foreign Direct Investments (1990-2012), Applied Econometrics and International Development, 14(1), pp. 133-146.

Trancparency international, TI report (2006). Available at URL www.transparency.org

Warren, M. E. (2004), What does corruption mean in a democracy? American journal of political science, pp.328-343. 